811.163.41'367

811.163.41'42

https://doi.org/10.18485/sj.2020.25.1.9

МИЛАНКА Ј. БАБИһ ${ }^{*}$

Универзитет у Источном Сарајеву

Филозофски факултет Пале
Оригинални научни рад

Примљен: 15. 10. 2019.

Прихваћен: 15. 01. 2020.

\title{
СЕМАНТИЧКО-ПРАГМАТИЧКЕ ФУНКЦИЈЕ АСИНТАКСИЧКИХ ЗАМЈЕНИЧКИХ ЕНКЛИТИКА У СРПСКОМ ЈЕЗИКУ
}

Замјеничке енклитике се у структури комуникативне реченице врло често употребљавају као асинтаксичке модално-експресивне ријечи. Њима се тада, невезано за било коју синтаксичку функцију, у оквиру разноврсних конверзационих говорних чинова, експлицира модални или емфатички став говорника. Као комуникативно-експресивне ријечи дативне и генитивно-акузативне замјеничке енклитике повезане су најчешће са другим конверзационим партикулама, са којима се усаглашавају, што их чини елементима битним за граматикализовање посебних (под)врста конверзационих говорних чинова. Зато се њихова улога у обликовању исказа посматра на интегралносинтаксичком плану - осим њихове комуникативне вриједности, скреће се пажња и на њихов (не)утицај на обликовање синтаксичке структуре и на везе које успостављају са ријечима у оквиру ње. Дескриптивном методом анализира се комбинаторичка природа тих веза, семантичке нијансе њиховог, у основи социјативног значења, те прагматичке функције које исказ, у који су инкорпориране, реализује у разговорном језику.

Кључне ријечи: асинтаксичке енклитике, замјенице, партикуле, датив, генитив, акузатив, говорни чин

"milanka.babic@ffuis.edu.ba 


\section{1. УВОД}

Замјеничке енклитике се, поред синтаксичке функције реченичног члана, у структури комуникативне реченице врло често употребљавају као модално-експресивне ријечи. Њима се тада, невезано за било коју синтаксичку функцију, у оквиру разноврсних конверзационих говорних чинова експлицира став говорника, какав је нпр. став присности изражен етичким дативом (Како си ми?), или се интензивира устаљено значење: квалификације (Што ти је стручњак!), непознатости неког сарджаја (Ко му га зна!), изненађења (Ето ти га сад!), обзнањивања изненадне појаве објекта у видном пољу говорника (Ено га Марко!), изражавања задовољства (Благо си га мени!), евалуативног става (Алал ти га вјера!), или пак образује формулаистички модел клетве, заклетве, псовке и сл. У обликовању таквих исказа дативне и генитивно-акузативне замјеничке енклитике, као формативни или као експлетивни чланови исказне структуре, повезане су најчешће са другим конверзационим партикулама, са којима се усаглашавају у оквиру говорног чина који експлицирају. Односно, њихове карактеристике и функције у оквиру говорних чинова конвенционалног карактера сасвим одговарају опису конверзачионих партикула, како их представља С. Ристић, а које „као експоненти конвенционалног говорног чина реализују компоненте са различитим илокуцијским садржајем. Сам говорни чин у коме се јављају установљава се друштвеним конвенцијама у којима се стереотипним формама компензира неприпремљеност конверзације и осигурава адекватна реакција било да се, у духу уљудног понашања, исказује задовољство и спремност на сарадњу (ословљавање, поздрављање, захваљивање, извињавање) било да се, супротно добрим манирима, исказује незадовољство нечим, негодовање (клетве, псовке и сл.). Партикуле као експоненти конвенционалног говорног чина јављају се често као једине или централне јединице његове стереотипне структуре. Њима се успостваља говорни контакт и припрема саговорник за комуникацијску сарадњу, исказује спремност за такву сарадњу, показује добронамјерност у тражењу и давању услуга, у исказивању солидарности, захваљивања и сл. [...]. Илокуцијски садржај партикула открива и социјално-психолошке димензије комуникације са елементима уљудних опхођења, статусних, старосних и других односа, толеранције, али и са елементима непожељног реаговања у исказивању нетрпељивости, незадовољства и сл.” (Ристић 1994: 152). На неконституентски статус енклитике тзв. етичког датива и на његову прагматичку вриједност указује се у бројним морфосинтаксичким студијама (в. Маретић 1963: 579; Стевановић 1969: 353-354; Палић 2010: 270-288; Прањковић 2013: 17-18), па тако датив у тој прагматичкој функцији, као и акузативну енклитику га, коју назива „емфатички акузатив”, А. Јањушевић убраја у „емфатичке партикуле”, будући да су то „замјенички облици који су изгубили своју деиктичку функцију, тако да се употребљавају само као знаци којима се постиже већа експресив- 
ност исказа” (Јањушевић 2018: 235). Управо та „већа експресивност исказа” и чини суштину стереотипних форми које функционишу са врло различитим прагматичким вриједностима, тј. без њих те форме не би ни постојале или не би постојале са степеном изражајности који у њих уносе асинтаксичке партикуле, па се у овом раду њихова улога у обликовању исказа посматра на интегралносинтаксичком плану - осим њихове комуникативне вриједности скреће се пажња и на њихов (не)утицај на обликовање синтаксичке структуре и на везе које успостављају са ријечима у оквиру ње. Дескриптивном методом анализира се комбинаторичка природа тих веза, семантичке нијансе њиховог, у основи социјативног значења, те прагматичке функције које исказ, у који су инкорпориране, реализује у разговорном језику.

\section{2. МОДАЛНО-ЕКСПРЕСИВНА ВРИЈЕДНОСТ АСИНТАКСИЧКИХ ЗАМЈЕНИЧКИХ ЕНКЛИТИКА}

Литература скреће пажњу на модално-експресивну вриједност енклитика личних замјеница, а претходно наведени примјери показују да оне могу да развијају пренесена значења, односно да се употребљавају метафорично. Такво одступање од уобичајене употребе означавања 1. лица говорника, 2. саговорника и 3. лица или нелица које је предмет говора представља њихову фигуративну транспозицију, у принципу засновану на привидном укључивању говорника и/или саговорника у говорни процес у коме нити учествује нити ће учествовати - што подразумијева успостављање релација комуникативне присности и саосјећајности. Зато је таква улога замјеничких енклитика увијек емоционално или интензификаторски експресивна. Фигуративну транспозицију у коме енклитика не денотира лице које изражава представља сљедећи примјер:

- Eно је сад. Немој и и као Јовандекина Мркуља. ДНБ, 198.

Образац ено је сад представља формулу за исказивање семантичко-прагматичке вриједности упозорења и у њему се енклитика 3. лица не мијења ни када се односи на присутног саговорника, па је у датом примјеру уочљива опозиција замјеничке енклитике 3 . л. ж. рода у генитиву (JE) и субјекта 2. лица (ТИ) из наредне реченице, при чему се оба облика односе на истог адресата. Тако је значење енклитике 3. лица JЕ фигуративном транспозицијом, која подразумијева еналагу лица, преусмјерено на 2. лице. Еналага и иначе као реторичко средство замјене једног граматичког облика другим који је неочекиван на мјесту на коме се појављује служи за скретање пажње на тако маркирану позицију (в. Багић 2012: 96), па је врло функционална и у говорном чину чија је илокуција усмјерена само на привлачење пажње као најаве за упозорење и сл. 
У фигуратим значењима заступљене су енклитике сва три лица, претежно једнине, а њихова дистрибуција зависи од усмјерености говорног чина на говорника, што актуализује дативну енклитику првог лица МИ (ријетко НАM), или на саговорника, када се актуализује енклитика другог лица ТИ (ријетко ВАМ), или пак на „неприсутно” лице или на нелице, када се укључује дативна енклитика МУ и генитивна или акузативна ГА, односно много рјеђе JE. Најфреквентнија у употреби јесте управо дативна енклитика другог лица једнине мушког рода (ТИ), а потом и трећег лица такође мушког рода једнине (МУ), те генитивно-акузативна за мушки род у једнини (ГА). Те категорије другог и трећег лица и једнине као броја јесу иначе категорије уопштавања и деперсонализације у српском језику, па је то подесан граматички оквир у коме се енклитички облици личних замјеница прекатегоризују у партикуле. Друго лице је лице уопштавња, заступљено у пословицама и изрекама, као и у устаљеним разговорним формама типа „Објашњаваш им, трудиш се, али до њих ништа не допире” у значењу „објашњавам им, трудим се”, тј. ЈА и свако ко се према послу односи исто као JА. Треће лице само по себи јесте неутрално у комуникативном процесу, па је енклитика 3. лица подесна форма за изражавање неодређеног, нереференцијалног садржаја - тако у изразима Ко му га зна или Ето ти га сад или Алал ти га вјера - ГА не упућује ни на шта што би имало функционално-семантичку вриједност у конструкцији. Такође ни МУ у исказу Ко му га зна не упућује на даљи објекат, него исказ као блокирана форма сабира та неодређена значења у јединствено значење да је нешто нејасно, да је знање говорника о нечему што је претходно дато несигурно, односно да му је садржај на који се читав израз односи непознат. Сама форма конструкције реторичког питања носи то значење, па су енклитике на синтаксичком и појмовно-логичком плану изостављиве (нпр. Ко зна = Нико не зна). Исказ без њих губи конотацију колоквијалне експресивности, јер обје енклитике функционишу у њему као експоненти неформалног говора и наглашеног говорниковог модалног (епистемичког) става. На сличан начин функционишу и енклитике у исказу какав је и Ето ти га сад - којим се изражава значење неочекиваности које говорник не усмјерава на саговорника дативном енклитиком ТИ, него обје енклитике представљају његов самоизраз, тј. саговорник при изрицању таквог исказа не мора уопште бити присутан нити се исказ мора односити на саговорника, што показују примјери у којима је исказ тога типа проширен и несаговорничким вокативом враже или ђаволе, са значењем негодовања због лоших прилика:

Ето ти га, враже, заглибили у лијево скретање! ДНБ, 133. Ето ти га, ђаволе, ита ћемо сад?! OM, 269.

На овај начин, као смисаоно-синтаксички плеонастичне, функционишу дате енклитике и у исказима евалуативног значења, нпр. Алал ти га вјера!, у којима се дативном енклитиком уз партикулу алал упућује похвала или 
покуда дативном адресату - у датом примјеру саговорнику, али то не мора бити нужно саговорник, па се умјесто енклитике ТИ, могу употријебити и енклитика 3. лица, нпр.: Алал мy/joj га вјера!. Осим тога, енклитике се могу и изоставити, посебно енклитика ГА (нпр.: Алал mu/мy/joj/вам/uм вјера!), а изостављива је и дативна, па исказ Алал вјера! контекстуално упућује на адресата или на предмет похвале. Та њихова формална плеонастичност упућује на то да ове енклитике, а посебно је то типично за генитивно-акузативно ГА, функционишу у датим конструкцијама као експресивне интензификаторске партикуле, односно да блокиране у облику, десемантизоване у својим деиктичким и конституентским функцијама, ове ријечи добијају статус експресивно-интензификаторских партикула. Склоност замјеничких енклитика да се категоријално транспонују у партикуле одражава се у инхрентним им карактеристикама, сродним карактеристикама партикула. И једне и друге су семантички сиромашне, а према мишљењу Д. Гортан-Премк, „сиромаштво семантичког садржаја значи и сиромаштво семантичких веза; а асемантичност искључује способност семантичког повезивања" (Гортан-Премк 1994: 128), односно неразвијен систем полисемије и других лексичко-семантичких категорија, што их води ка модалном значењу носилаца личног става говорног лица или интензивирања значења пунозначног реченичног члана, а тиме и ка синтаксичкој неконституентности.

\section{3. ПРАГМАТИЧКЕ ФУНКЦИЈЕ АСИНТАКСИЧКИХ ЗАМЈЕНИЧКИХ ЕНКЛИТИКА}

Осим као емфатичка партикула која појачава значење наведених исказа упозорења (Ено је сад!), реторичких питања којима се изражава да је нешто непознато (Ко му га зна!), исказа евалуативног карактера (Алал ти га вје$p a !)$, неконституентска енклитика ГА употребљава се у генитивном облику у конструкцијама са презентативним партикулама ево, ето, ено у којима је маркер предмета обзнањивања, односно изненадног појављивања у видном пољу говорника:

\section{Ено га, људи! Нам је! ДНБ, 129.}

Да је у питању генитив обзнањивањ, , а не акузатив, показује и супституција енклитике именицом женског рода (која јасно показује разлику између генитива и акузатива), па у датом контексту није могуће употријебити нпр. акузатив: *Ено Ану!, али јесте генитив: Ено Ане! ${ }^{1}$

${ }^{1}$ Дилему генитив или акузатив уз презентативе у исказима изненадног појављивања разријешила је у корист генитива С. Кордић (в. Кордић 2002: 115). Шире о облицима уз презентативе в.: Бабић 2010: 164-166. 
Генитивно-акузативно ГА псовке функционише у исказу типа Ево вам га (на)! - у коме је ГА, било у генитивном било у акузативном облику (именица коју супституише може бити употријебљена и у једном и у другом облику), маркер фалусне симболике. Формант ове конструкције је и партикула ево, као проксимал који непосредно обиљежава соматски простор говорника - што је неопходно јер је изрицање овакве псовке најчешће праћено и говорниковим невербалним знацима „одмјеравања од шаке до лакта”.

Бројније од генитивно-акузативних јесу прагматичке функције дативних неконституентских енклитика. У једнотомном Речнику српског језика Матице српске, осим као дативна замјеничка енклитика, ТИ је одређено и као „б. речщца за појачавање (етички датив). - Он ти је добро. в. у заклетви. - Иди, вере ти!” (РМС 2007: 1317). Тиме су одређене и двије од бројних прагматичких функција асинтаксичке дативне енклитике, које се у општем смислу своде на социјативну вриједност, односно на функције дијалошких маркера, будући да слабијом или јачом деиксом или пак фигуративно у контекст укључују (не)солидарност више лица.

У литератури и иначе најчешће помињана прагматичка функција дативне енклитике јесте етички датив, који је плеонастичко ${ }^{2}$ карактера и служи да се њиме изрази присност између говорника и саговрника, обиљежена обликом првог или другог лица, тј. најчешће енклитикама МИ и ТИ (в. Симеон 1969/1: 210):

Како си ми? Шта ми радиш?; Да ми се лепо проведеш!; Да си ми здрав! ПМ, 488; Ово ти је Милан, син мог пријатељь. ТБВ, 156; Моја Митра ти готово не проговара, рекао је комшија Никола. ТБВ, 158; Ја ти, док не сване, у кревет не могу. Мени ти је свеједно. ТБВ, 187.

Датив констатовања користи, односно штете упућује са ослабљеном референцијом на саговорника:

Омутавио од гранате. Ш'а ти је-тутије. ТБВ, 67; То ти је кад се љууди повуку, ко у мишју рупу. ТБВ, 124; E, то ти и јест мука с мјехуром. Стално ти се пиша. ТБВ, 143; Ето, то ти је рат. ТБВ, 154; Тако ти је то, рекао је. ТБВ, 214; Тако ти је то кад се свакој божјој рђи и почмигљивиу додијели право критике и самокритике. ДНБ, 135.

И овај дативни облик енклитике плеонастичког је карактера и изостављив је без штете по синтаксички и смисаони садржај, нпр.: Ш'a je - my je; То u јесте мука с мјехуром; То је рат; Тако је то.

${ }^{2}$ „Облици $м и, т и$ јављају се често без икакве потребе (плеонастично), а старински облик cu друкчије се и не јавља него тако. На пр.: Њу ми пита громовник Илија. Смерно ми се цару поклонише. Лепа $m и$ је у Алаге љуба! Чудна $m и$ ми годиница дође! Тешко $c u$ мени без тебе! Благо си теби без њега!” (Лалевић 1932: 46). 
Датив скретања пажње реализује се у конструкцији са презентативном партикулом ето:

И каже спаваћемо у соби, с оне стране са које не пуца! ... Ето ти што не пуца, несрећо моја! ТБВ, 35; Ето ти што су наши бории: на Неретви смо баиали топове ... дај ти сад разуми ово расипништво. ДНБ, 143; Ето ти сад, па ти види: да су прилагивали -jecy. ДНБ, 174.

Конструкција Ето ти има значење скретања пажње на неки садржај који се наглашава, са нијансама слабије или јаче израженог упозорења. Овај израз служи и за изражавање изненађења, невјерице, чуђења, разних нијанси неслагања:

Ето ти, опет си насјео фашистичкој пропаганди. ДНБ, 131; Напопастио се ту: узми сира, тако Франиузи раде! Ето ти сад Франиуза, нек ти они плате! ОМ, 270; Отиште се и -иоч! - бубну о земьу као да га бачише с тавана. - Ето ти, де! ДНБ, 154.

Комбинована са генитивом, дативна енклитика, у конструкцији са императивом пази, значење скретања пажње трансформише у евалуативно, са подругљивим или уопште ироничним конотацијама. Тако се реализује датив омаловажавања:

Пази ми господина! Је ли ти то Станко Веселица напунио главу? ДНБ, 179; Пази ми га! Ти опет овдје - згражава се машинист. ДНБ, 182.

Тако употријебљен датив у облику је првог лица, јер изражава негативан вриједносни став говорника према саговорнику или према трећим лицима или предметима:

И они ми нашли пити! Видим ли вас јом једном заједно, поломићу вам ноге! ТБВ,

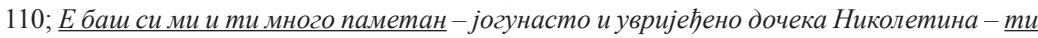
ми га нешто знаш! ДНБ, $139 ;$ И то ми је нека гурава вајда - с ниподаштавањем ииједи Пађен. ОМ, 268; Бам си ми у форми данас! ПМ, 488.

Датив (за)клетве, с обзиром на редукованост конструкције или на саму семантику клетве и преклињања, мора да означи адресата, па је у конструкцији неопходан, али је његова синтаксичка функција дисперзивна - несводљива на једну вриједност, јер се у њему комбинују значење адресата и посесивно, јер је адресат одређен управо посесивним значењем, будући да предмет заклињања припада адресату и упућује на њега:

Пусти га, Ахмо, матере ти, рекао је Един. ТБВ, 67; Јој, мали, иут' више матере mи, рекао је Злаја. ТБВ, 94; А реи'ми, живота ти, о ћему прићате? ТБВ, 167; Едине, шта то радиш, кукала ти мајка! ТБВ, 69.

У конструкцијама јадања и кукања, дезактуализацијом лица, дативно ТИ усмјерава се као интензификаторска партикула на говорника самог, који је уз то обиљежен и другим граматичким категоријама првог лица, а неријетко и пуним обликом датива замјенице првог лица једнине:

Кукаван ти сам, шта то радиш? - зграну се Николетина. ДНБ, 137; Ајме мени, јадан ти сам, оде и командир - закука војник. ДНБ, 136; Ајме ти је мени, опет га нема! - пљескао је Јовица. ДНБ, 136. 
Облици кукаван сам, јадан сам и ајме мени којима се изражава говорниково јадање додатно су наглашени дативном енклитиком ТИ.

Датив псовке функционише у еуфемистички редукованој конструкцији без глагола псовања:

Мајку му, Ђе ли ово паде! ТБВ, 75; Аух, божију ти күкавичу! ОМ, 270; Их, божију mи репу још ће ми се матер и удати, па остадох сироче. ОМ, 279; Само полако, цану ли вам ваму, говорила је. ТБВ, 15; Ђе сте вас двој'иа кренули, нану ли вам јетимску! ТБВ, 166.

Дативна енклитика је неизостављива јер упућује на адресата, а псовка се интензивира и плеонастичном присвојном замјеницом истог лица (нану ли вам вашу).

Еуфемистичку структуру псовке представља и колоквијална конструкција у сљедећем примјеру:

Хајде, рођо, све му ьубим, не буди на крај сриа! ДНБ, 182.

Замјеном глагола псовања презентом љуббим, добија се додатно маркирана псовка која има вриједност добронамјерног говорниковог става убјеђивања саговорника.

\section{4. ЗАКЉУЧНА РАЗМАТРАҢА}

Анализа показује да је улога ових ријечи у прагматичкој структури исказа формативна чак и када су плеонастичне у структурно-синтаксичком смислу, односно када их је могуће изоставити а да исказ не буде аграматичан и бесмислен. Тако нпр. питање Шта ми радиш? - упућено саговорнику остаје и даље питање и без енклитичког датива (Шта радиш?), али губи компоненту социјативне солидарности и емпатије коју говорник изражава према саговорнику. То етичком дативу даје експлетивни, а не плеонастички статус у конструкцији, јер се са њим и без њега мијења комуникативно-прагматичка вриједност исказа, тј. искази са етичким дативом и без њега у опозицији су субјективно-експресивног и неутралног типа питања. Дативна прагмема првог лица МИ експлицира ангажованог, заинтересованог и саговорнику наклоњеног говорника, што изостаје у неутралном исказу. За комуникативну синтаксу није битан критеријум да ли је неки језички елеменат у оквиру синтаксичке јединице структурно неопходан или није уколико је на плану значења и функције говорног чина релевантан. Па зато плеонастичност асинтаксичке дативне енклитике на граматичком плану не подразумијева и еквивалентност плеонастичности на прагматичко-семантичком плану, јер се са њом и без ње не преноси исти (под)тип говорног чина. То показује и један од њених семантичких типова који има функцију евалуативног датива, као нпр. у исказу То ми је велики научник! Ако овај исказ упоредимо са њему структурно-синтаксички еквивалентним То је велики научник - врло јасно се уочава њихова различи- 
та семантичко-прагматичка вриједност. Исказ без дативне енклитике има неутрално идентификационо, односно позитивно квалификативно значење. Исказ са дативном енклитиком мијења неутрално значење у експресивно и изражава негативну квалификацију. Дативна енклитика у њему модализатор је субјективног става говорног лица који се уопштено подводи под израз „према мом мишљењу", па дативна енкитика има функцију експресеме која путем иронијског трансфера семантички садржај афирмативне квалификације преводи у супротну вриједност. То потврђује да су на прагматичко-семантичком плану асинтаксичке енклитике експлетивне прагмеме.

У другом типу конструкција, као што је нпр. заклетва Мајке ми моје, асинтаксичка замјеничкиа енклитика није изостављива, па се њеним елиминисањем губи и смисаона и синтаксичка структура (*Мајке моје). Формативна улога датива ту је неспорна, јер без њега нема ни исказа тог типа. Његова вриједност у датој конструкцији није сводљива ни на етички нити на посесивни датив, него је шире модалног карактера. Тај датив је семантички вишекомпонентан - садржи и компоненту посесивности у односу на предмет заклињања, али је и носилац субјективног става вредновања значаја предмета заклињања, па упућује на експеријенцентни имлицитни субјекат (аналогно имперсоналним конструкцијама са дативним логичким субјектом - носиоцем психофизиолошког стања, нпр. Тешко ми је). Иако је конструкција без њега аграматична, не може се говорити о његовој конституентској синтаксичкој функцији, али може о формативној, јер је неопходан у исказу и на структурном и на семантичком плану. Обје те функције асинтаксичких партикула - и формативна и експлетивна - у интегралносинтаксичком (комуникативно-граматичком) смислу битне су за функционисање исказа, за његов семантичко-прагматички потенцијал, јер граматикализују посебне (под)врсте конверзационих говорних чинова, па се у суштини и у општем смислу значења термина - може говорити о функторској улози асинтаксичких замјеничких енклитика у структури исказа. Функтори су - према Љ. Поповићу - ,речи и спојеви речи који служе за граматикализацију употребних вредности независних и зависних предикатских реченица", односно то су ријечи којима се граматикализује одређени тип исказа, које „представљају структурну компоненту синтаксичког обрасца” (Поповић 1998: 385-388) - помоћу које се, дакле, реализује нека од типичних комуникативних функција, будући да је „употребна вредност реченице” исто што и исказ.

Ова група ријечи није, дакле, хомогена у свим аспектима своје функције и (дез)актуалзације категоријално-граматичког значења. Будући да су замјенице упућивачке ријечи, замјеничке енклитике управо ту компоненту свога категоријалног значења упућивања на одређени референт дијелом или сасвим дезактуализују у оквиру типичног говорног чина чија су формативна средства. Тако дативне енклитике 1. и 2. лица (МИ - ТИ) упућују на лица учесника у 
говорној ситуацији, на модалну вриједност садржаја који исказ експлицира за њих или у односу на њих или на њихов емфатички став, док енклитике 3. лица - било да је у питању дативно МУ, било генитивно/акузативно ГА (рјеђе JE) - углавном дезактуализују деиктичко, а развијају интензификаторско значење. Нпр.: Ко му га зна; Шта му га знам; Тако му је то; Тако му га то некако дође и сл. Интензификација овог типа не утиче битније на смисаону вриједност исказа, јер исказ Ко зна и без енклитика 3. лица (МУ, ГА) има вриједност реторичког питања са супротним семантичким потенцијалом Нико не зна. И искази Тако му је то и Тако му га то некако дође, без енклитика, имају значење општег, ковенционално-конверзационих закључака Тако је то и Тако то некако дође који се изричу на карају описа неке ситуације. Овакав вид функционисања јасно је представљен и у лексикографском опису ових ријечи. У РМС је ГА у основном значењу наведено као енклитички облик генитива и акузатива личне замјенице 3 . лица једнине мушког и средњег рода, али и, под ознаком разговорно - као „плеонастично, без значења а. обично у узвичним реченицама, у претњи, клетви, завету, за појачавање исказа и сл. - Овде га нећеш остати ни часа. Ја га тамо не идем ни мртав. Мој ти га Марко побеже. Баш си га претерао. б. са узв. „благо” и „тешко” (често са речциом „си”). - Благо си га мени. Тешко си га њему. в. у конструкиијама: ко (бог, враг, ђаво) га зна (би га знао и сл.) - Враг би га знао шта ће бити. г. у конструкиијама са речју шта (који значи мноштво) - Шта га је паса!" (РМС 2007: 180). Тиме се ове ријечи потврђују у статусу реченичних партикула - изгубиле су конституентску вриједност и деиктичко значење лица и функционишу као појачивачи емфатичког или когнитивног исказног садржаја. Степен интензивирања који се помоћу њих постиже врло је изразит, што показују конструкције реторичког питања и идиоматизираних анафоричних конструкција закључивања, које се односе на претходно изречена саопштења у дијалогу. У исказима тврђења који се формирају са општим замјеницама (ко, шта) - чије је значење семантиком реторичког питања трансформисано у одричне (нико, ништа), као и у онима са демонстративном замјеницом то и/или прилогом тако - којима се такође изричу универзалне и наглашено важеће тврдње - замјеничке енклитике функционишу и са вриједношћу универзалних квантификатора. Интензивирање замјеничком енклитиком 2. и 3. лица (Ко му га зна! и То ти је тако!) постиже се удаљавањем деиксе облика МУ, ГА и ТИ од лица и антиципирањем значења универзалних квантификатора све и свако, који значење исказа у цјелини (све) представљају као општеважећег (за свакога). Тако се исказ реторичког питања универзализује као одричан за свакога, а искази са демонстративима то и тако као потврдни за свакога. 


\section{ИЗВОРИ}

ДНБ: В. Ćopić, Doživljaji Nikoletine Bursaća, Beograd - Sarajevo: Prosveta - Svjetlost - Veselin Masleša, 1980.

OM: B. Ćopić, Odumiranje međeda, Beograd - Sarajevo: Prosveta - Svjetlost - Veselin Masleša, 1980.

ПМ: P. Mrazović, (u saradnji sa Z. Vukadinović), Gramatika srpskog jezika za strance, Sremski Karlovci - Novi Sad: Izdavačka knjižarnica Zorana Stojanovića.

TБB: V. Kecmanović, Top je bio vreo, Beograd: VIA PRINT, 2008.

\section{ЛИТЕРАТУРА}

Бабић 2010: М. Бабић, Огледи из прагматичке синтаксе, Источно Сарајево: Филозофски факултет.

Бабић 2019: М. Бабић, Екскламативне конструкиије у српском језику, Андрићград: Андрићев институт.

Багић 2012: K. Bagić, Rječnik stilskih figura, Zagreb: Školska knjiga.

Гортан-Премк 1994: Д. Гортан-Премк, Типови и врсте речи, Јужнословенски филолог, L, Београд: Институт за српски језик САНУ, 117-128.

Јањушевић 2018: А. Јањушевић, Интензификаторске партикуле у савременом српском језику, Косовска Митровица - Никшић: Филозофски факултет - Матица српска, Друштво чланова у Црној Гори.

Кордић 2002: S. Kordić, Riječi na granici punoznačnosti, Zagreb: Hrvatska sveučilišna naklada.

Маретић 1963: T. Maretić, Gramatika hrvatskoga ili srpskoga knjževnog jezika, Zagreb: Matica hrvatska.

Мразовић 2009: P. Mrazović, (u saradnji sa Z. Vukadinović), Gramatika srpskog jezika za strance, Sremski Karlovci - Novi Sad: Izdavačka knjižarnica Zorana Stojanovića.

Палић 2010: I. Palić, Dativ u bosanskom jeziku, Sarajevo: Bookline.

Поповић 1998: Љ. Поповић, Реченични функтори, Научни састанак слависта у Вукове дане, 27/2, Београд: МСЦ, 385-403.

Прањковић 2013: I. Pranjković, Gramatička značenja, Zagreb: Matica hrvatska. 
Ристић 1994: С: Ристић, Илокуцијски аспекти употребе партикула, Јужнословенски филолог, L, Београд: Институт за српски језик САНУ, $143-154$.

Симеон 1969/1: R. Simeon, Enciklopedijski rječnik lingvističkih naziva, knj. 1, Zagreb: Matica hrvatska.

Стевановић 1969: М. Стевановић, Савремени српскохрватски језик II, Београд: Научна књига.

\section{SEMANTIC-PRAGMATIC FUNCTIONS OF ASYNTACTIC PRONOUN ENCLITICS IN THE SERBIAN LANGUAGE}

\section{Summary}

Pronoun enclitics are often used in the structure of communicative sentences as asyntactic modal-expressive words. Then, irrespective of any syntactic function, within the various conversational speech acts, the modal or emphatic attitude of the speaker (such as the attitude of intimacy expressed by an ethical dative) is explicated, or the meaning of an established statement (qualification, disclosure of sudden appearance of an object) is intensified, or even they form a formulaic model of curse, oath, swearing, etc. In shaping such statements, the dative and genitive-accusative pronoun enclitics, as formative or as explicit members of the statement structure, are most often associated with other conversational particles, which they correlate within the speech act they are explaining. Their role in the utterance shows that the criterion of whether a linguistic element within a syntactic unit is structurally necessary or not if relevant on the plane of the meaning and function of the speech act.

Therefore, even when they are pleonastic in syntactic terms, these enclitic-particles are not pleonastic in the semantic-pragmatic plane, on which they function either as exclusive words that complete the pragmatic value of the utterance or are formative means of idiomatic utterances. This makes them essential for the grammaticality of particular (sub)types of conversational speech acts.

Keywords: asyntactic enclitics, pronouns, particles, dative, genitive, accusative, speech act. 